\title{
Neither a Wife nor a Whore: Deconstructing Feminine Icons in Catherine Breillat's Une vieille maîtresse
}

\author{
Douglas Keesey
}

\begin{abstract}
This article undertakes a close reading of Catherine Breillat's recent film Une vieille maitresse (2007) to show why this, her first heritage film, is nevertheless strongly relevant to the gender politics of today. The author argues that Breillat's cinematic deconstruction of differences between women is designed to undo the polarising effect of patriarchal representations of women as madonnas or whores - media images still prevalent even in these days of mixité and parité. Despite a tendency on the part of some reviewers to take the film's gender images at face value, the author argues that Breillat's interest lies not in the predictable (and socially conservative) contrast between fixed polarities, but in the uncertain outcome of a dynamic internal conflict, in the (progressive) possibility of indeterminate gender roles. Through a close examination of the film's mirror imagery, deconstructive editing and transvestic costumes, the author demonstrates how Breillat both exaggerates and confuses feminine icons in order to highlight them as patriarchal stereotypes and to deconstruct their opposition. The article also draws on paratextual evidence, including the striking poster art used in the film's advertising campaign as well as the revealing statements made at film festivals by Breillat and her lead actress.
\end{abstract}

There is a scene in Catherine Breillat's $\dot{A}$ ma sœur! (2001) where Anaïs and Elena stand side by side regarding their reflections in the bathroom mirror. At this moment, these two girls who would appear to be polar opposites - the ugly and the beautiful, the rebel and the conformist, the cynic and the sentimentalist marvel at the realisation that they are in fact sisters. It is as though, by standing outside of and gazing upon the dichotomous images of themselves that they normally unconsciously inhabit, the sisters are able to perceive a likeness between them beyond the differences into which they have been categorised by patriarchal society. As Anaïs remarks to Elena: "When I hate you, I look at you 
and I can't anymore; it's like hating a part of myself". ${ }^{1}$ Breillat's filmic images act like this mirror, revealing to viewers that the war between women is often one between socially projected stereotypes; that it is possible to move beyond merely acting out the prescribed conflict between contrasting female roles and to work through differences toward a new performance of sisterly solidarity.

In Breillat's recent film Une vieille maîtresse (2007), which is based on a novel by Jules Barbey d'Aurevilly set in the Paris of 1835, the dark-haired mistress Vellini and her blonde maid Oliva, who is a double for the fair-haired and virginal Hermangarde, stand side by side and gaze upon their images in a mirror. Vellini's lover Ryno has just left her to go to his bride-to-be Hermangarde, but Breillat has Oliva - a proxy for Hermangarde - lean in to comfort Vellini with a kiss, a kiss that gradually becomes passionate as if the "virtuous" blonde also harboured a "sinful" sensuality, a desire to meld with the "dark" mistress until there is no difference between them. Breillat's cinematic deconstruction of differences is designed to undo the polarising effect of patriarchal representations of women as madonnas or whores - media images still prevalent even in these days of mixité and parité, of equal access and equal representation. As Abigail Gregory and Ursula Tidd note in their book Women in Contemporary France:

If, despite legislative gains and amendments to the French constitution designed to improve women's status, women are sidelined ... as "only" wives and mothers or represented by the media as little more than sexual objects who are readily available for male consumption, this militates against a public perception of women as autonomous citizens. Such representations of women in a society whose institutions and organizational cultures remain largely patriarchal tend only to incite and perpetuate misogynistic practices. (Gregory \& Tidd 2000, p. 215)

The French film poster for Une vieille maittresse shows side-by-side images of Hermangarde and Vellini, of the idealised blonde in her bridal veil and the "dark lady" with her bewitching black hair whose strands form the shape of a diabolically inverted heart on her forehead. While some reviewers tended to take these images at face value in describing the film's conflict as one between an angel and a devil, a virgin and a whore, Breillat juxtaposes these feminine icons in order to expose them as patriarchal stereotypes and to deconstruct their opposition. (In fact, the two images on the poster are not distinct but overlap across the diagonal of the bridal veil, as if lifting the veil from Hermangarde's face would be to reveal Vellini's.) Breillat analyses these feminine icons to reveal that the difference between them is really a difference within, an identity crisis provoked by contradictory patriarchal demands:

The confrontation between the conventional beauty of an iconic virgin, the wife and good girl virtuously hiding her feelings and repressing her desires like 
an ideal fiancée, and the sovereign woman, the Amazon who takes and whose declared desires incarnate this beauty that is so loudly decried in a world where people reprove, under the name of "ugliness", a woman's assertion of liberty, her manifest sensuality and her power over men. (Breillat 2007, p. iv)

Hermangarde can live up to the image of angelic beauty only so long as she represses her sensuality, sacrificing a part of herself for patriarchal religion, while Vellini is viewed as the incarnation of the devil because she refuses to repress her desires; the beauty of her spirit goes unrecognised as she is reduced to her bodily parts, which men both crave and fear.

In one scene, as a naked Vellini climaxes under Ryno's heaving body as they make love on a tiger-skin rug, the camera cuts to a white-clad Hermangarde doing her embroidery while she waits for Ryno to come courting. But to see in this a simple contrast between the old mistress as the embodiment of animal passion and the future bride as a model of virtue and propriety would be to identify each woman with her role under patriarchy, to deny her her other part. These two women are also linked across the cut, reminding us of the socially sanctified marriage that the sensual Vellini will never have and of the sexual expression that the properly passive and pure Hermangarde will not get to enjoy. When Ryno finally arrives, Hermangarde's grandmother permits him to give the bride-to-be nothing but a chaste kiss on the forehead, even though the young woman's eyes indicate that she longs for much more. Then, once the two have been married, the bride herself limits Ryno to a kiss on her forehead as she sits there reading the Bible across from her sleeping grandmother, who has accompanied the couple to their conjugal retreat. Hermangarde, believing that she must uphold the scriptural image of a saintly wife in case the eyes of society should fall upon her, here renders herself into a frigid icon, blocking the fulfilment of her own desires.

But it is important not to mistake this internalisation of patriarchal religion's prohibitions for some immutable truth about Hermangarde's angelic purity or prudishness, for this would be to further the typecasting of her character and to miss the drama of her internal conflict. The unladylike zeal with which Hermangarde herself pushes open the church doors on the day of her wedding strongly suggests that she is eager for her bridal veil to be lifted. Furthermore, even though Vellini is more often associated with the primordial passion of the sea, Hermangarde's willingness to brave the rising tide during honeymoon walks with Ryno suggests desires within her that could match his. Thus, when Hermangarde says, "I must really accustom myself to the waves and the wind since I am the wife of a man in love with the sea", her comment is more than an unwitting reminder that Ryno is still more attached to his passionate mistress than to his prudish young wife; it is also an indication of Hermangarde's own sexual potential. And when this young wife, dressed in a churchly blue dress and riding a pure white horse, nevertheless spurs the beast to a gallop in an effort to catch up with her husband and his mount, she displays an animal passion that could keep Ryno from riding off to Vellini. 
But suddenly, without our seeing any sex scene, Ryno is stroking Hermangarde's white pregnant belly ("This is my son") and forbidding her any more riding of horses. Thus, Hermangarde goes directly from chaste bride to Virgin Mother with no sexuality to sully her in between, for in Ryno's compartmentalising view, women are either wives or whores, mothers or mistresses. He can no more imagine sharing his desires with his sainted spouse than he could contemplate sanctifying sex with Vellini through marriage. And yet, once again, Breillat's interest lies not in the predictable (and socially conservative) contrast between fixed polarities, but in the uncertain outcome of a dynamic internal conflict, in the (progressive) possibility of deconstructing gender roles. So, Breillat gives us a scene in which, after witnessing her husband having sex with Vellini in a fisherman's hut, Hermangarde drags herself home through the mud and collapses on the marital bed. Upon his return, Ryno sees his virtuous wife felled by the shock of his own sexual vices, her skirts sullied by the desire to which she has been exposed. In tenderly removing her shoes and soiled stockings while Hermangarde lies there in a faint, Ryno can be seen as trying to restore the purity and angelic innocence of her image by returning to his own role of chastely affectionate and devoted husband. And yet his slow stripping-off of her stockings, his exposure of more and more of her bare skin while a fire crackles and flares up in the hearth, is the most sensual scene between them. Does the fact that she is (apparently) unconscious allow him to carry over to his wife some of the passion he has just been experiencing with his mistress? Does his tender regard for his wife help to purify desires that would otherwise seem just basely physical? Does the idea that she has been somewhat "sullied" by the sex she has witnessed make it possible for him to contemplate passion with her? In this moment which cuts across and blurs categories, passion and purity can be seen as one in a kind of double exposure, the mistress revealed behind the bridal veil, the skin beneath the spouse's stocking.

It is not a moment that lasts, for as Ryno leans across the marital bed to give his wife a comforting and/or sensual kiss, she raises a white pillow between them and will thereafter punish him for his infidelity by holding herself aloof from him and immersing herself in the role of suffering martyr or mater dolorosa. This soothes her injured pride, but it also confines her within a purely spiritual role defined as defiantly separate from human warmth or sexuality. It thus closes forever the brief possibility that Ryno might find sexual as well as spiritual fulfilment with his spouse, and it makes a certainty of the very thing that Hermangarde had striven to avoid: that her husband will leave her, his sainted wife, seated high up in their box at the opera, and ride off to see his mistress Vellini for the satisfaction of his baser desires, which he does at the end of the film.

At the 2007 New York Film Festival, actress Roxane Mesquida spoke about the difficulty of conveying with her eyes and her body the internal conflict within a mostly silent and rigid character like Hermangarde, who battles against but eventually surrenders to becoming a frozen feminine icon. In order to conform to social expectations, this angelic aristocrat must appear to model a "pure love" for Ryno while stifling her other feelings of passion, jealousy and outrage at his 
adultery: "She loves Ryno with a pure love. Her rank prevents her from expressing herself, she remains a prisoner of social constraints, she appears cold and never cries in front of him" (Mesquida, quoted in Flach Film 2007). Many reviewers have remarked upon the scene in which Vellini reacts to Ryno's marriage by nearly throwing herself off a cliff so that he will save her by taking her into his arms, because we expect Vellini to behave true to type in exhibiting a passion unto death. However, the scene where Hermangarde is moved to weep and nearly stagger off that same cliff at the realisation of Ryno's infidelity has gone virtually unnoticed for it does not seem to suit her character, and yet this moment where Hermangarde expresses the Vellini inside herself - reinforced by an opera singer's lament on the soundtrack - is charged with great importance by Breillat. As Mesquida notes:

[Hermangarde] found herself alone and could finally cry. And so there were two really very different states, one more formal and the other more instinctive. The contrast between the moments when Hermangarde upholds her rank and those when she falls into sheer emotion was impressive. (Flach Film 2007)

The emotive moment on the cliff is important because it shows Hermangarde's potential to break from the social stereotype of frigid purity and to express the passionate side of her character, "the fever under the ice" (Breillat, quoted in Leffler 2007).

It is, in fact, the sight of "the other woman", Vellini, which has brought out the other side of Hermangarde. The proper young wife in her blue dress and yellow bonnet peers down from the cliff's edge to see the old mistress seated at the water's edge, smoking a cigarro and wearing red skirts. But this confrontation does not merely represent the clash between two contrary types of women, the lady and the whore. It also highlights the conventionality and artificiality of these women's sartorial differences, revealing them to be patriarchal investments. As Hermangarde comes face to face with Vellini and the two women exchange glances, the potential is there for each to recognise the other as her mirror image, reflecting back to her the other side of her own self, the part of her she does not get to play in the one-dimensional performance pre-scripted for her under patriarchy. Indeed, for a moment the two women almost seem to exchange roles as well as glances when Vellini's face hardens into a cool mask of superiority and Hermangarde's face breaks into passionate tears. Unfortunately, this brief role reversal is not accompanied by the recognition of unity within difference; instead, the two women continue to act out the socially scripted conflict between them. But it is important for us to recognise the deconstructive potential in these encounters between stereotyped opposites, even if the female characters themselves gain only a glimpse of their likeness and quickly revert to type. When Hermangarde follows Ryno to the fisherman's hut and turns away after seeing her husband in the arms of his mistress, is there a moment between innocence and haughty outrage, a "through the looking glass" moment when seeing the brazenly naked Vellini allows Hermangarde to imagine herself making passionate love to her husband - a moment just before she gathers her green 
cloak jealously around her and reverts to type as the martyred wife? Similarly, after Vellini wore black to the wedding of her lover Ryno and his virginal bride and before Vellini followed the couple on their honeymoon to ruin it, was there a moment between mourning and vengeful seduction, a moment when seeing the perfectly happy Hermangarde allowed Vellini to imagine herself wearing the bridal veil in a socially sanctified marriage?

Certainly, the real drama of Vellini's character is not to be found in her performance as a man's mistress or as a femme fatale, but in the ways she attempts to exceed these rote roles defined by patriarchal desires and dreads. Ryno, a young libertine, first hears about Vellini from a fellow rake, Mareuil, who is plotting to seduce her away from her elderly husband, Sir Reginald Annesley. Ryno's initial interest in Vellini is thus as a trophy in a sexual competition among men; to take her as his mistress would be to prove his superior manhood. But she resists being reduced to the role of a sexual possession; she will not merely succumb to him. When Ryno first lays eyes on her as she is seated in a carriage, Vellini is wearing a black mantilla of exotic-erotic allure and licking a phallic ice cream. Her sensuality attracts him, but he is also frightened and repelled by the avidity of her appetite, which leads him to label her an "ugly girl". As Breillat has explained: "What is 'ugliness' at the time? It's a question of sensuality. At one moment, Sophia Loren was ugly, her lips were too large ... Jeanne Moreau was ugly because too sensual. Brigitte Bardot was vulgar" (Raya 2006). Even more disturbing, Vellini is also wearing a large silver cross around her neck, which means that her blatant sensuality is combined with an ostentatious spirituality, the two extremes meeting in a blasphemous challenge to patriarchal religion's division between body and soul. It seems likely that much of Ryno's fascination with Vellini is driven by a masculinist desire to reduce her troubling contradictions, to pin her down as a woman, a body, his possession. And yet, from their very first meeting, there is also the sense that she exerts a fascination over him because he cannot contain or comprehend her, because her unsettling combination of categories is moving him toward a whole new way of being: "Is it her little body that is bewitching or is it her soul?" asks one man in the novel, and another says, "what she has and what l've seen only in her is a fascination of the whole being, which is specifically neither in the spirit nor in the body, but everywhere and nowhere" (Barbey d'Aurevilly 1979, pp. 271, 113).

Later, at a high society party, the men pass around a box at the dinner table in order to shock and titillate their aristocratic female companions when they see the pornographic sketch inside of a man taking a woman more ferarum, but when Ryno hands Vellini the box, she does not even bother to open it: she is beyond both prurience and prudery. A frankly sexual being in her amply revealing décolleté dress, Vellini knows that in the midst of such "respectable society" her effrontery might be considered sinful or devilish, and in fact she has come to this costume party dressed as a devil, both performing the role in which they would cast her and mocking it at the same time. And lest her performance be belittled as that of a mere "she-devil" (diablesse), a feminine masquerade of power, Vellini insists that she is playing "the Devil" (Diable), adding that she "hates 
everything that is feminine - except in young men". With this provocative statement, Vellini masculinises herself and feminises Ryno. The libertine who would make her his conquest finds the gender polarity diabolically reversed as she asserts sexual agency over him. Is there a moment between his desire for dominance and his fear of emasculation when Ryno can imagine himself enjoying being taken by a woman? Breillat has spoken of her own erotic reveries and utopian dreams concerning "younger men" like Ryno, those with "a lock of hair that falls over an eye, lips almost like a girl's, a kind of androgyny, ambiguity" (Clément 2002, p. 294). In Breillat's view: "Humanity as a whole should be a lot more androgynous ... Women can have the desire to conquer these men who are more feminine without that making the men less strong, sexually and intellectually" (Breillat 2006, p. 54).

Vellini continues her cross-dressing when, after Ryno's subsequent attempts to carry her off by force provoke a duel with her husband Sir Reginald, she slicks back her hair and dons trousers in order to pass as a man and act as her husband's second at the duel. In league with the gun whose bullet will penetrate Ryno's flesh, Vellini is here associated with phallic violence, and Ryno reinforces this association by noting that Vellini's father was a bullfighter whose stabs would draw blood from the bull: "Since the toreador's daughter has a thirst for blood, let her see it flow!" Indeed, after Ryno has been shot and is laid out on his sickbed, Vellini leans aggressively over him to lick the wound near his heart, exclaiming to a startled doctor: "I want to drink his blood and no one will stop me!" In this scene, Vellini would appear to be the very incarnation of a femme fatale, a diabolically dominant woman whose aggressive advances invert the "natural" gender order, a vamp whose predatory sexuality sucks the life out of a man. But we should not confuse Vellini with patriarchy's phobic view of her, even if she has been playing up this devilish part as a counter-offensive against the men who would relegate her to a passive role. (There is a sense in which she would rather see Ryno killed than be conquered by his brute force or be won by him as his prize possession in a duel between men.) When Vellini then asks the doctor whether Ryno is going to die, the grave concern in her voice revises the patriarchal view of her bloodthirstiness and re-performs it in our mind's eye as a primally physical attempt to cure his wound, a giving or sharing of life rather than a taking of it, a loving infusion or transfusion of spirit rather than a draining that leaves behind a dead body. Thus, Vellini's "animal" licking is also spiritual in import, uniting body and soul in a kind of blood pact or pagan marriage to Ryno, in what the novel calls "the terrible and sacred influence of this blood communion" (Barbey d'Aurevilly 1979, p. 184). (Earlier, at the dinner party, Ryno had grabbed Vellini's wine glass to drink from it, but she had snatched it back from him, breaking the glass and bloodying her hand in the process. Could it be that, behind Ryno's grasping aggressiveness, there was also a hidden desire for communion with her?)

As the days pass while the wounded Ryno hovers between life and death, Vellini haunts his room in her black lace dress with a dagger at her side, but then this spider woman bends over her fallen prey to whisper in his ear: "I surrender, Ryno. I fought hard, but I am vanquished". When she no longer has to play the 
femme fatale in defence against his overbearing advances, Vellini is freed to perform another part, to be touched by his wound, to give herself over to tenderness. And, just as she is no longer a black widow, so she also departs from the equally reductive but opposite role of the docile wife. "Tu es ma femme!" Sir Reginald tells her, making - as the French language does - "woman" synonymous with "wife", as if her whole being lay in the part that is his possession. But Vellini leaves him, grateful that in marrying her he gave her social legitimacy, but unwilling to imprison herself in a passionless marriage or within the role of a merely lawful spouse. As Vellini begins a passionate affair with the recovering Ryno, locking him in a room whenever she goes out, it could be said that she has simply turned the tables on a man and is now the one making him her "prisoner" and her "slave", but theirs is a playful game of dominance and submission where he willingly gives her the phallus/key which she uses to enclose him, letting him enter her. As Vellini and Ryno make love, Breillat shows their matching smooth bodies and the dark curly hair on their heads becoming confused, much as woman and man, passive and active, bottom and top become reversible and interchangeable. And as Ryno lies back in bed while Vellini smells his underarms and pubic hair, we see a woman as sexual subject enjoying a man's body without his thinking himself demeaned or objectified as mere flesh. As Breillat has said in connection with this film's sensual scenes: "contrary to what most people think, I've always thought that physical love is always the core of emotional love between two beings" (Ebiri 2007).

But Vellini's boundaryless relationship with Ryno, in which she is more than a mistress and less than a wife, can find no place in patriarchal society, and so the two are exiled to a hut in the burning deserts of Algeria. Here, their passion produces a daughter beautiful in her nakedness, a child with the same dark unruly hair and free spirit as her mother. However, lacking the protection and social stability normally afforded by the institutions of church and marriage (as oppressive as these institutions are), the family is vulnerable, as indicated when their daughter is stung by a scorpion and dies. It is important to note that, just as Vellini and Ryno's marriageless passion results in a dead child, so Hermangarde and Ryno's passionless marriage leads to a miscarriage. With the horrible matching deaths of these two offspring, one to the socially disapproved mistress and the other to the sensually deprived wife, Breillat points again to the necessity of reconciling opposites, for in her view: "We are social beings, very strongly so. But we are also amorous beings, very strongly as well. Therefore we must reconcile these two things" (Breillat 2004).

After the death of their daughter, Vellini straddles and mounts Ryno, engaging him in a frenzied coupling. Ryno's phobic reaction is to revert to his earlier view of Vellini as a femme fatale or sexual demon consuming his manly spirit:

This thing [she did with me] wasn't love but an endless fury, a kind of barbaric rape. I rejected it with all my soul ... I no longer existed in her eyes, except that she was a creature so wholly constituted for sensual pleasure that she always had to have it. At such moments, I hated her. 
Tragically, Ryno's demonising of Vellini prevents him from recognising that her behaviour is a complex reaction to the grief they both share and which they could have helped each other to work through. Vellini does choke Ryno's neck during sex, but she also tears at her own hair and face, wanting to destroy herself and join her child in death rather than be parted from her daughter. (Ryno had to insist that Vellini allow the dead child to be removed from her arms and then he had to hold her back from leaping onto the funeral pyre.) Vellini's furious lovemaking with Ryno next to the funeral pyre could be an anguished attempt to conceive another child. What Ryno can only see as a vamp with an insatiable appetite could also be viewed as a grieving mother desperate to create a new life. The sensual mistress is simultaneously a would-be mother; her passion is continuous with a life-giving spirit. Ironically, if Vellini's passion has turned violent, it is in maddened protest against being reduced to a mere mistress, against a society that will not accept her as a wife and mother or protect her child. If Vellini is to some extent a carnal demon, it is because patriarchy has left her little other part to play.

In the end, Vellini does not suck the life out of Ryno or strangle her lover to death like the vamp or Venus flytrap she is feared to be, but neither does she passively allow him to discard her like one of his other past mistresses when he is done using her flesh. Instead, by insisting that their "liaison" will have no "dénouement", Vellini maintains that their relationship was not merely a brief carnal affair, and when she follows Ryno on his honeymoon and he leaves his bride to return to Vellini, she lays claim to an emotional-spiritual fidelity on Ryno's part greater than that which he has for his lawful spouse. Ryno may believe that it is only Vellini's sensuality that lures him back to her, but what he fails to see is that Vellini's spiritual attraction is inextricably bound up with her sexuality, that hers is indeed "a fascination of the whole being, which is specifically neither in the spirit nor in the body, but everywhere and nowhere" (Barbey d'Aurevilly 1979, p. 113). When the two have sex in the fisherman's hut, their bodies are scissored with Ryno lying horizontally and Vellini upside down under him on the vertical. It is possible to view this scene through patriarchal eyes, in the way that Ryno at least in part seems to experience it: he has fallen prey to a succubus, a female demon (with a snake bracelet) who merely uses his sex for her own pleasure as their conjoined bodies form the shape of a diabolically inverted cross. But we can also see the scene more as Vellini tries to live it, as a mutual giving and taking of love, the consummation of her "marriage" to Ryno, the height of purity reached through the depths of passion. At the 2007 New York Film Festival, Breillat compared the look on Vellini's face during orgasm to the rapturous expression of Saint Teresa in Bernini's sculpture of the Ecstasy of Saint Teresa. As Breillat (2006, p. 69) has noted elsewhere (taking her cue from Jacques Lacan): "the face of a woman who comes is a true mystery! ... It's the rapture depicted by Bernini, the face of Saint Teresa, mystical ecstasy, carnal ecstasy". In coming to this unity of body and soul beyond the division between mistress and wife, Vellini passes all patriarchal understanding. Perhaps, in seeing themselves reflected in Vellini's image, some viewers can find a similar peace. 


\section{Acknowledgements}

My heartfelt thanks to the organisers - Richard Rushton and Lynsey RussellWatts - and to the attendees of the 2008 International Conference on Catherine Breillat for their spirited debate and provocative questions, which prompted further thinking and marked improvements in this article.

\section{References}

Barbey d'Aurevilly, J. (1979) Une vieille maîtresse, Gallimard, Paris.

Breillat, C. (2004) 'Interview with Director Catherine Breillat', supplement on Anatomy of Hell DVD, Tartan Video.

Breillat, C. (2006) Corps amoureux: entretiens avec Claire Vassé, Denoël, Paris.

Breillat, C. (2007) 'Préface', in Barbey d'Aurevilly, J., Une vieille maîtresse, Bartillat, Paris, pp. i-iv.

Clément, J. (2002) 'Catherine Breillat', in LesFemmeset l'amour, Stock, Paris, pp. 267-300.

Ebiri, B. (2007) 'Q \& A: Catherine Breillat', Nerve Film Lounge, http://www.nerve.com/ FilmLounge/interview/CatherineBreillat (accessed 23 February 2008).

Flach Film (2007) 'Dossier de presse: Une vieille maîtresse', Flach Film, Paris, available from http: //www.flachfilm.com/index.php?page=film\&id=72.

Gregory, A. \& Tidd, U. (eds) (2000) Women in Contemporary France, Berg, Oxford.

Leffler, R. (2007) 'Interview with Catherine Breillat', Hollywood Reporter, 25 May.

Raya, A. (2006) 'Catherine Breillat - Asia Argento - Sulfurieuses!', Paris Match, 27 July. 
Copyright of Journal for Cultural Research is the property of Routledge and its content may not be copied or emailed to multiple sites or posted to a listserv without the copyright holder's express written permission. However, users may print, download, or email articles for individual use. 